\title{
Manajemen Kewirausahaan Koperasi Pondok Pesantren Al-Urwatul Wutsqaa
}

\author{
Muhammad Saleh \\ I Nyoman Budiono \\ Nidaul Islam \\ Institut Agama Islam Negeri (IAIN) Parepare \\ muhammadsaleh@iainpare.ac.id
}

\begin{abstract}
Abstrak
Artikel ini bertujuan untuk mengetahui penerapan fungsi-fungsi manajemen serta bentuk-bentuk kewirausahaan koperasi pada Pondok Pesantren AlUrwatul Wusqaa di Kelurahan Benteng Kabupaten Sidrap. Penelitian ini menggunakan Metode Kualitatif dengan pendekatan empiris, dimana dihasilkan data deskriptif berupa kata-kata tertulis ataupun lisan dari individu-individu dan perilaku yang diamati. Pelaksanaan fungsi-fungsi manajemen Koperasi Pondok Pesantren Al-Urwatul Wutsqaa di Kabupaten Sidrap secara umum masih belum berjalan sesuai dengan aturan perkoperasian. Fungsi perencanaan telah dilakukan namun masih terbatas pada perencanaan pengembangan bangunan toko. Fungsi pengorganisasian masih sangat lemah, Rapat Anggota Tahunan dan Pembagian Sisa Hasil Usaha tidak dilakukan, simpanan wajib sudah tidak pernah dipungut, struktur kepengurusan dan keanggotaan tidak pernah dilakukan pembaharuan. Fungsi Penggerakan (motivating), fungsi pengawasan (controlling) dan fungsi penilaian (evaluating) masih terbatas pada usaha pertokoan saja, sedangkan pada usaha-usaha lainnya tidak berjalan sebagaimana mestinya. Bentukbentuk kewirausahaan koperasi yang pernah ada antara lain usaha pertokoan santri putra dan santri putri, usaha mesin jahit, dan usaha simpan pinjam dan usaha catering. Namun demikian saat ini usaha simpan pinjam dan usaha mesin jahit sudah tidak berjalan. Alasan tidak berjalannya usaha simpan pinjam karena sudah tidak pernah dilakukan setoran simpanan wajib sehinga modal koperasi terbatas dan tidak dapat dikelola pada usaha simpan pinjam. Sedangkan alasan tidak berjalannya usaha mesin jahit dikarenakan mesin jahit tersebut telah rusak dan tidak produktif lagi.
\end{abstract}

Kata Kunci : Manajemen, Kewirausahaan, Koperasi

\section{Pendahuluan}

Pembangunan nasional Indonesia bertujuan menciptakan masyarakat yang adil dan makmur dimana pembangunan sektor ekonomi menjadi salah 
satu prioritas. Dalam rangka menciptakan pertumbuhan ekonomi dan pemerataan pembangunan secara bersama-sama, maka koperasi dijadikan soko guru ekonomi nasional seperti dijabarkan dalam Pasal 33 ayat 1 UUD 1945; "Perekonomian disusun sebagai usaha bersama berdasarkan azas kekeluargaan". ${ }^{1}$ Asas kekeluargaan dalam koperasi merupakan bagian penting yang tidak dapat dipisahkan satu sama lainnya, hal ini sesuai dengan jiwa masyarakat yang saling tolong menolong dan bergotong royong dalam kehidupan sehari-hari.

Keunggulan bersaing koperasi timbul karena anggota koperasi menjadi pemilik sekaligus pelanggan dari produk koperasi itu sendiri, hal ini tidak dimiliki oleh badan usaha lainnya. Koperasi dapat melakukan kerjasama dengan koperasi lainnya sesuai dengan sifat koperasi yang bekerjasama dan bergotong royong dalam azas kekeluargaan. Disamping itu, keunggulan bersaing koperasi juga diperoleh dari adanya perhatian pemerintah dalam memajukan ekonomi kerakyatan melalui koperasi. Adanya keunggulan bersaing dari koperasi yang berpihak pada kepentingan rakyat berdampak pada tumbuhnya koperasi diberbagai sendi kehdupan bangsa.

Pondok pesantren adalah tempat dimana para santri tinggal dan menetap dalam mempelajari dan mendalami ilmu Agama Islam. Di dalam pondok pesanten tinggal para santri dan guru secara bersama meakukan proses belajar mengajar di bidang Agama Islam untuk periode waktu yang telah ditetapkan.

Sebagai bagian dari komponen bangsa, pondok pesantren juga aktif melakukan kegiatan kewirausahaan koperasi disamping tugas utamanya di bidang pendidikan keagamaan. Kewirausahaan koperasi yang dibentukdi lingkungan Pondok Pesantren diharapkan mampu berperan dalam ayat1.

${ }^{1}$ Undang-undang Dasar Republik Indonesia, Undang-undang Dasar 1945, pasal 33 
memenuhi kebutuhan Santri khususnya dan secara umum mampu berperan dalam memenuhi kebutuhan masyarakat sekitarnya. Kehadiran kewirausahaan koperasi di lingkungan pondok pesantren diharapkan juga mampu berperan dalam menumbuhkan jiwa dan minat kewirausahaan dikalangan santri.

Koperasi Pondok Pesantren Al-Urwatul Wutsqaa berdiri sejak tahun 2000-an. Koperasi ini telah menunjukan kemajuan yang cukup baik, hal ini tampak dari beberapai jenis usaha yang dijalankannya, sehingga sangat menarik untuk mengetahui pelaksanaan fungsi-fungsi manajemen dan bentuk-bentuk usaha yang dijalankana pada koperasi Pondok Pesantren $\mathrm{Al}$ Urwatul Wutsqaa.

Menurut Sondang. P. Siagian dalam Hasibuan, fungsi-fungsi manajemen mencakup : ${ }^{2}$

1. Perencanaan (Planning) dapat didefinisikan sebagai keseluruhan proses pemikiran dan penentuan secara matang tentang hal-hal yang akan dikerjakan dimasa yang akan dating dalam rangka mencapai tujuan yang telah ditetapkan.

2. Pengorganisasian (Organizing) adalah keseluruhan proses pengelompokan orangorang, alat-alat, tugas-tugas, tanggung jawab, dan wewenang sedemikian rupa

3. Penggerakan (Motivating) dapat didefinisikan sebagai keseluruhan proses pemberian dorongan bekerja kepada para bawahan sedemikian rupa sehingga mereka mau bekerja dengan ihlas demi tercapainya tujuan organisasi dengan efisien dan ekonomis.

4. Pengawasan (Controlling) adalah proses pengamatan pelaksanaan seluruh kegiatan organisasi untuk menjamin agar semua pekerjaan yang 2007), h. 3.

${ }^{2}$ Hasibuan Malayu, S.P. Manajemen Sumber Daya Manusia, (Jakarta: Bumi Aksara, 
sedang dilakukan berjalan sesuai dengan rencana yang telah ditentukan sebelumnya.

5. Penilaian (Evaluation) adalah fungsi organik administrasi dan manajemen yang terakhir. Definisianya ialah proses pengukuran dan perbandingan hasil-hasil pekerjaan yang nyatanya dicapai dengan hasilhasil yang seharusnya dicapai.

\section{Penerapan Fungsi-Fungsi Manajemen Koperasi Pondok Pesantern Al- Urwatul Wutsqaa}

Fungsi-fungsi manajemen adalah hal yang sangat penting dalam sebuah kegiatan perusahaan, baik perusahaan yang berorientasi kepada laba maupun perusahaan nirlaba, tak terkecuali dalam operasional usaha koperasi pondok pesantren Al-Urwatul Wutsqaa, berikut hasil penelitian tentang penerapan fungsi manajemen :

\section{Fungsi Perencanaan}

Tujuan utama dari Koperasi adalah memakmurkan perekonomian anggota dan kelompok, mulai dari pengawas, pengurus, anggota dan sebagainya. Dari tujuan tersebut pengurus harus mampu membuat perencanaan yang bersifat konstruktif untuk mencapai tujuan dari Kopontren. Tujuan Kopontren Al-Urwatul Wutsqaa salah satunya adalah mengoptimalkan usaha ekonomi di lingkungan Pondok Pesantren Modern Islam Al-Urwatul Wutsqaa.

Perencanaan yang dilakukan oleh Kopontren Al-Urwatul Wutsqaa antara lain Pangadaan kantor koperasi dan pertokoan, pengadaan pelatihanpelatihan, tertibnya admiistrasi dan laporan keuangan serta meningkatkan usaha-usaha yang dijalankan Kopontren Al Urwatul Wutsqaa. ${ }^{3}$

3 Darmawati,Pengurus Koperasi Pondok Pesantren Al-Urwatul Wutsqaa, wawancara di Kelurahan Benteng, Kecamatan Baranti, Kabupaten Sidrap, (2 Agustus 2018) 


\section{Fungsi Pengorganisasian}

Pelaksanaan Funngsi Pengorganisasian pada Kopontren Al Urwatul Wutsqaa sebagai berikut :4

a. Rapat Anggota Tahunan

RAT atau singkatan dari Rapat Anggota Tahunan adalah wajib yang dilakukan pengurus dalam koperasi. Rapat anggota tahunan membahas mengenai pertanggungjawaban pengurus koperasi yang telah dipilih untuk menjalan kegiatan yang telah direncakan pada tahapan sebelumnya. Sehingga semakin banyak anggota yang ikut serta dan terlibat dalam rapat anggoita tahunan, maka semakin baik dan dapat menghasilkan keputusan sesuai dengan kebutuhan anggota koperasi. Pada beberapa tahun terakhir, Rapat Anggota Tahunan tidak pernah dilakukan. Hal ini disadari oleh pengurus koperasi sebagai suatu yang sebenarnya harus dilaksanakan. Terbersit niatan dari pengurus koperasi untuk segera melakukan perbaikanperbaikan khususnya mengenai pelaksanaan Rapat Anggota Tahunan.

b. Pengurus Koperasi

Tidak dilaksanakannya Rapat Anggota Tahunan, berdampak pada kepengurusan koperasi yang terpusat pada orang-orang lama saja dan tidak terbaharukan. Hal ini sangat riskan mengingat wewenang dan tanggung jawab pengurus sangatlah strategis, antara lain : Memimpin organisasi dan usaha koperasi, menyelenggarakan rapat anggota dan rapat pengurus serta mempertanggungjawabkan kepada anggota rapat mengenai pelaksanaan tugas kepengurusannya dan lain-lain.

c. Keanggotaan Koperasi

4 Pondok Pesantren Al-Urwatul Wutsqaa, Dokumentasi peneliti di Kelurahan Benteng, Kecamatan Baranti, Kabupaten Sidrap (2 Agustus 2018) 
Anggota Kopontren Al-Urwatul Wutsqaa berjumlah 29 anggota yaitu terdiri dari tenaga pengajar. Anggota Kopontren Al Urwatul Wutsqaa adalah pemilik dan sekaligus pengguna jasa Kopontren Al Urwatul Wutsqaa yang harus dicatat dalam buku daftar keanggotaan Kopontren Al Urwatul Wutsqaa. Setiap anggota dipersyaratkan membayar simpanan pokok dan simpanan wajib yang besarnya tergantung dari kesepakatan dalam rapat anggota. Namun demikian sudah beberapa tahun ini anggota koperasi tidak lagi membayar simpanan wajibnya. Ini merupakan suatu hal yang harus segera diperbaiki.

\section{Fungsi Penggerakan (Motivating)}

Pada awal terbentuknya koperasi Al Urwatul Wutsqaa banyak kegiatan yang dijalankan oleh pihak pengurus. Menurut ketua koperasi, ada beberapa kegiatan yang tidak berjalan, yaitu kegiatan simpan pinjam dan kegiatan usaha menjahit. Alasan tidak berjalannya usaha simpan pinjam karena para anggota koperasi sudah tidak aktif melakukan setoran simpanan wajib. Sedangkan alasan tidak berjalannya usaha mesin jahit karena sebagian besar mesin tersebut telah rusak. Saat ini kegiatan Kopontren Al Urwatul Wutsqaa terfokus pada usaha pertokoan saja, yaitu terdiri dari satu unit toko santri putra dan satu unit toko santri putri. Perkembangan yang cukup besar dari usaha pertokoan Kopontren Al-Urwatul Wutsqaa disebabkan peningkatan jumlah santri setiap tahunnya dalam pondok pesantren sehingga kebutuhan sehari-hari yang semakin meningkat. Menurut Ketua Kopontren Al-Urwatul Wutsqaa sangat perlu pembenahan kembali terkait 
penertiban administrasi keanggotaan. Sebab, saat ini sistem administrasi tidak berjalan sesuai dengan aturan berkoperasi. ${ }^{5}$

Kendala yang sering dihadapi Kopontren Al-Urwatul Wutsqaa adalah pembagian waktu yang kadang bertabrakan dengan jam mengajar. Sehingga pihak Kopontren Al-Urwatul Wutsqaa harus membagai tugas untuk melakukan penjagaan, atau terkadang pengurus menyewa masyarakat yang dipercayakan di lingkungan sekitar untuk menjaga pertokoan tersebut. 6

Pemberian motivasi untuk lebih memacu kegiatan usaha koperasi pondok pesantren Al-Urwatul Wutsqaa masih sangatlah lemah. Namun demikian pada beberapa hal pemberian motivasi telah dilaksanakan antara lain dengan memberikan kompensasi terhadap para pekerja dengan tepat waktu, menyediakan berbagai jenis produk yang dibutuhkan para santri, terus mengembangkan bangunan fisik koperasi sehingga kegiatan pertokoannya dapat berjalan dengan baik. Diharapkan kedepannya pemberian motivasi juga dapat dilaksanakan untuk hal-hal lainnya seperti pemberian motivasi untuk melaksanakan Rapat Anggota tahunan Koperasi, pemberian motivasi untuk melaksanakan berbagai kegiatan kewirausahaan lainnya selain usaha pertokoan.

4. Fungsi Pengawasan (Controlling)

Pengawasan sangatlah penting untuk mengetahui hasil pelaksanaan, kesalahan, kegagalan, kemudian dilakukan perbaikan dan mencegah terulangnya kembali tersebut. Pengawas adalah perangkat organisasi yang mendapat kuasa dari rapat anggota untuk mengawasi pelaksanaan

5 Darmawati, Pengurus Koperasi Pondok Pesantren Al-Urwatul Wutsqaa, wawancara di Kelurahan Benteng, Kecamatan Baranti, Kabupaten Sidrap, (2 Agustus 2018)

6Pondok Pesantren Al-Urwatul Wutsqaa,Ketua Koperasi, wawancara peneliti di Kelurahan benteng, Kecamatan Baranti, Kabupaten Sidrap (2 Agustus 2018) 
keputusan rapat anggota yang khususnya menyangkut organisasi, kelembagaan, pendidikan, serta penyuluhan. Pengawas dipilih dari, oleh, dan untuk anggota. Ketua dan pengurus koperasi saling berkoordinasi dalam melakukan kegiatan pengawasan Kopontren Al-Urwatul Wutsqaa. Pengawasan pada Kopontren Al-Urwatul Wutsqaa juga didapatkan dari luar Kopontren Al-Urwatul Wutsqaa yaitu Pemerintahan Daerah Sidrap melalui Dinas Perindustrian Perdagangan dan Koperasi.

5. Fungsi Penilaian (Evaluating)

Pelaksanaan Fungsi penilaian secara umum belum berjalan dengan baik. Bentuk-Bentuk evaluasi seperti Rapat Anggota Tahunan dan Pembagian Sisa hasil Usaha belum dilaksanakan. Bahkan rapat-rapat koordinasi jarang dilakukan. Para pengurus menyadari bahwa pelaksanaan manajemen koperasi ini belum sesuai dengan sistem atau aturan yang seharusnya berlaku pada perkoperasian. Evaluasi yang dilaksanakan masih sebatas pada unit usaha pertokoan yaitu dengan terus memperhatikan kebutuhankebutuhan para santri dan ketersediaan stock barang dagangan sehingga para santri merasa puas dimana kebutuhannya dapat terpenuhi oleh koperasi dengan harga yang wajar.

\section{Bentuk-Bentuk Kewirausahaan Koperasi Pondok Pesantren Al-Urwatul Wutsqaa}

1. Unit usaha Pertokoan

Unit Usaha pertokoan Kopotren Al-Urwatul Wutsqaa menyediakan berbagai kebutuhan sehari-hari untuk santri dan para guru. Adanya anjuran kepada santri untuk berpatisipsi dalam pengembangan Kopotren Al-Urwatul 
Wutsqaa menyebabkan unit pertokoan ini mampu bertahansampai saat ini (lebih kurang 18 tahun).

Dalam wawancara yang dilakukan peneliti dengan salah satu santri, mengatakan bahwa pelayanan dalam unit pertokoan tersebut dinilai baik, tersedia berbagai macam jenis barang yang dijual serta harga barang dagangan yang sangat terjangkau, dengan sistem penjualan dilakukan secara tunai. $^{7}$

Koperasi juga selalu menjaga hubungan baik dengan para supplier. Salah satunya adalah Toko Hikmah yang memasok kebutuhan pokok seharihari. Hubungan dengan toko ini telah terjalin kurang lebih 5 tahun dan selama ini tidak pernah bermasalah dan koperasi dapat memenuhi kewajibannya dengan baik.

2. Unit Usaha Mesin Jahit

Modal usaha tempat praktek keterampilan usaha menjahit dan konveksi Pondok Pesantren berasal dari Kementerian Koperasi dan UKM pada Tahun 2011. Dengan bantuan inilah, pesantren mengembangkan usaha ini agar dapat membantu salah satu kebutuhan pesantren dan juga sebagai penunjang perekonomian pesantren. Program sewa kelola mesin jahit menjadi bagian sumber pendapatan tambahan Kopontren, mesin jahit yang disewa kelola kepada masyarakat berjumlah sekitar sepuluh buah.

Hasil observasi peneliti, program ini sudah tidak berjalan seperti awalnya. Menurut hasil wawancara dengan Ketua Koperasi, mengatakan bahwa mesin jahit tersebut telah rusak, mungkin disebabkan usia yang sudah

7Saraswati Baharuddin, Santri Kelas 1 Aliyah, wawancara di Kopotren Al-Urwatul Wutsqaa (5 Agustus 2018) 
cukup lama dan perawatan yang tidak memadai, disamping itu perhatian pengurus koperasi sudah tidak terfokus pada jenis usaha ini.

3. Unit Usaha Simpan Pinjam

Salah satu kegiatan Kopontren Al-Urwatul Wutsqaa adalah menyalurkan dana kredit ke anggota dan masyarakat disekitar pondok pesantren. Program simpan pinjam yang peruntukkan untuk masyarakat merupakan bentuk kepedulian koperasi pesantren terhadap masyarakat disekitar pesantren. Namun beberapa tahun belakangan ini kegiatan koperasi berupa simpan pinjam tidak dijalankan lagi, hal ini karena kurangnya kesadaran dari anggota koperasi untuk membayar simpanan wajib. Disamping itu para anggota koperasi kebanyakan tenaga honor dan pendapatannya tidak tetap sehingga tidak memungkinkan lagi untuk melakukan kegitan simpan pinjam, jadi untuk saat ini kami hanya berfokus pada pertokoan saja. ${ }^{8}$

4. Problematika Manajemen Koperasi Al-Urwatul Wutsqaa.

Pondok pesantren Al-Urwatul Wutsqaa mempunyai potensi yang cukup besar untuk berkembang dimana jumlah santrinya saat ini sudah lebih dari 1000 orang dan jumlah tenaga pengajar sebanyak kurang lebih 70 orang.

Saat ini koperasi mempunyai 2 unit toko, 1 unit Toko santri Putra dan 1 unit toko santri putri. Koperasi ini juga mendapat bantuan dari berupa depot air minum yang akan beroperasi dalam waktu dekat.

Belum terlaksananya fungsi-fungsi manajemen koperasi sebagaimana mestinya sesuai dengan aturan perkoperasian, terutama dalam pelaksanaan Rapat Anggota Tahunan yang tidak dilaksanakan beberapa tahun ini

8 Darmawati,Pengurus Koperasi Pondok Pesantren Al-Urwatul Wutsqaa, wawancara di Kelurahan Benteng, Kecamatan Baranti, Kabupaten Sidrap, (2 Agustus 2018) 
menjadikan problem yang harus segera diatasi. Namun demikian pengurus koperasi berharap bisa segera melaksanakan manajemen koperasi ini sesuai dengan aturan yang berlaku.

\section{Penutup}

Pelaksanaan fungsi-fungsi manajemen Koperasi Pondok Pesantren AlUrwatul Wutsqaa di Kabupaten Sidrap secara umum masih belum berjalan sesuai dengan aturan perkoperasian. Fungsi perencanaan telah dilakukan namun masih terbatas pada perencanaan pengembangan bangunan toko. Fungsi pengorganisasian masih sangat lemah, Rapat Anggota Tahunan dan Pembagian Sisa Hasil Usaha tidak dilakukan, simpanan wajib sudah tidak pernah dipungut, struktur kepengurusan dan keanggotaan tidak pernah dilakukan pembaharuan. Fungsi Penggerakan (motivating), fungsi pengawasan (controlling) dan fungsi penilaian (evaluating) masih terbatas pada usaha pertokoan saja, sedangkan pada usaha-usaha lainnya tidak berjalan sebagaimana mestinya.

Bentuk-Bentuk kewirausahaan koperasi yang pernah ada antara lain usaha pertokoan santri putra dan santri putri, usaha mesin jahit, dan usaha simpan pinjam dan usaha catering. Namun demikian saat ini usaha simpan pinjam dan usaha mesin jahit sudah tidak berjalan. Alasan tidak berjalannya usaha simpan pinjam karena sudah tidak pernah dilakukan setoran simpanan wajib sehinga modal koperasi terbatas dan tidak dapat dikelola pada usaha simpan pinjam. Sedangkan alasan tidak berjalanya usaha mesin jahit dikarenakan mesin jahit tersebut telah rusak dan tidak produktif lagi. Pendapatan yang diperoleh dari usaha yang masih berjalan ini kurang lebih 
sebesar Rp. 30 jutaan perbulan dan digunakan untuk mendukung kesejahteraan guru-guru. Pondok pesantren juga memperoleh bantuan dari para alumni berupa 1 unit mesin produksi air galon dan saat ini masih pada tahap pemasangan.

\section{Daftar Pustaka}

A. Haidar Putra Daulay. 2009. Pemberdayaan Pendidikan Islam di Indonesia. Jakarta: Rineka Cipta.

Abd Rahman an Nahlawi. 1992. Prinsip-prinsip dn Metode Pendidikan Islam, diterjemahkan Dahlan \& Sulaiman. Bandung: Diponegoro.

Al Gazali. 1977. Ihya Ulumuddin, Jilid III. Dar-al Mishri:Beirut..

Ali, Mukti. 1999. KH Ali Ma'shum Perjuangan dan pemikirannya. Yogyakarta.

Burhanuddin, Tamyiz. 2001. Akhlak Pesantren:SolusiBagi Kerusakan Akhlak,. Yogyakarta: ITTIQA Press.

D. Made Dharmawati. 2016. Kewirausahaan. Jakarta: Rajawali Pers.

Danim dan Yunan Danim. 2010. Administrasi Sekolah \& Manajemen Kelas. Bandung: Pustaka Setia.

Dharmawati, D. Made. 2016. Kewirausahaan. Jakarta: Rajawali Pers.

George, Terry dan Leslie. 2010. Dasar-dasarManajemen. Jakarta: BumiAksara.

Handoko, T. Hani. 1995. Manajemen. Yogyakarta: BPFE.

Hendar, Manajemen Perusahaan Koperasi : Pokok-pokok Pikiran Mengenai Manajemen dan Kewirausahaan Koperasi (Jakarta: Erlangga, 2010), h. 28.

Hendar. 2010. Manajemen Perusahaan Koperasi: Pokok-pokok Pikiran Mengenai Manajemen dan Kewirausahaan Koperasi. Jakarta: Erlangga.

Hendrojogi. 2002. Koperasi : Azas-azas Teori dan Praktek, edisi revisi. Jakarta: PT. Raja Grafindo..

Hendrojogi. 2002. Koperasi : Azas-azas Teori dan Praktek, edisi revisi (Jakarta: PT. Raja Grafindo. 
Indrawati, Penerapan Fungsi Manajemen di Sekolah Percontohan SDN 107415 Tanjung Sari Kecamatan Batang Kuis Kabupaten Deli Serdang. http://digilib.unimed.ac.id/577/1/Penerapan\%20fungsi\%20manaje men\%20di\%20sekolah.pdf. Diakses pada tanggal 17 Novenber 2018

Ivone Ria Fianty Rumbrapuk, dkk, Efektifitas Penerapan Fungsi Manajemen dalam Pencapaian Kinerja Puskesmas di Kabupaten Bovendigoel. http://pasca.unhas.ac.id/jurnal/files/547d32985403353761ae41184 7f9f1eb.pdf. Diakses pada tanggal 17 Novenber 2018.

Kasmir. 2016. Kewirausahaan. edisi revisi. Cet. XII; Jakarta: Rajawali Pers.

Kotler, Philip . 2009. Manajemen Pemasaran. Cet XII. Jakarta: PT. Indeks.

Longenecker, Justin G., Carlos W. Moore, dan J. William Petty. 2001. Kewirausahaan : Manajemen Usaha Kecil, edisi I. Jakarta: Salemba Empat.

2001. Kewirausahaan : Manajemen Usaha Kecil, edisi I. Jakarta: Salemba Empat.

M. Manullang. 1996. Dasar-Dasar Manajemen. Jakarta: Ghalia Indonesia.

Malayu, Hasibuan S.P. 2007. Manajemen Sumber Daya Manusia. Jakarta: Bumi Aksara.

Moh. Alifuddin dan Mashur Razak. 2015. Kewirausahaan Strategi Membangun Kerajaan Bisnis, .Jakarta: MagnasciptPublising.

Moh. Alifuddin dan Mashur Razak. 2015. Kewirausahaan Strategi Membangun Kerajaan Bisnis. Jakarta: MagnasciptPublising.

Mohammad, Rusli Rukka. 2011. Buku Ajar Kewirausahaan. Makassar: Lembaga Kajian dan Pengembangan Pendidikan Universitas Hasanudin..

Munir dan Wahyu Ilahi. 2009. Manajemen Dakwah, edisi pertama (Cet. II; Jakarta: Kencana.

Nawawi, Hadari. 1990. Pendidikan dalam Islam. Surabaya: Al-Ikhlas.

Nawawi, Ismail. 2013. Kewirausahaan Bisnis Kontemporer Jakarta: VIV Press,.

Nurul Yakin, Studi Kasus Pola Manajemen Pondok Pesantren Al-Raisiyah di Kota Mataram. Diterbitkan pada jurnal Studi Keislaman Volume 18 Nomor 11 (Juni) 2014. https://www.researchgate.net/publication/294728312 diakses pada tanggal 17 November 2017.

Prawirosenton, Suyadi. 2002. Pengantar Bisnis Modern : Studi kasus Indonesia dan Analisis Kuantitatif. Jakarta: PT. Bumi Aksara.. 
Prawirosentono, Suyadi. 2002. Pengantar Bisnis Modern : Studi kasus Indonesia dan Analisis Kuantitatif. Jakarta: PT. Bumi Aksara..

Revrisond, Baswir. 2000. Koperasi Indonesia. Edisi Pertama. Yogakarta: BPFE UGM.

Ridha, Rasyid. Tafsir al-Manar, Jilid II. Mesir:Maktabah al-Qahirah, tt.

Sjarkowi, F. Dan M.Sufri. 2004. Manajemen Agribisnis. Palembang : CV. Baldal Grafiti Press.

Sunarya, Abas. 2011. Kewirausahaan. Yogyakarta: Penerbit Andi.

Suryana. 2006. Kewirausahaan dalam Praktis :Kiat dan Proses Menuju Sukses. Jakarta: Salemba.

Suwendi.1999. Rekonstruksi Sistem Pendidikan Pesantren. Bandung; Pustaka Hidayah.

Swasta, Basu DH dan T. Hani Handoko.1997. Manajemen Pemasaran Modern,. Yogyakarta: Liberty.

Undang-undang Dasar Republik Indonesia, Undang-undang Dasar 1945

Undang-undang Republik Indonesia, Undang-Undang No. 25 tahun 1992.

\section{REFERENSI PENELITIAN}

Dinas Koperasi. 2018.Usaha Kecil Menengah dan Perdagangan, Sistem Informasi Untuk Layanan Koperasi, Situs Pemerintah https://www.diskup.kapuashulukab.go.id/tugas-pokok-dan-fungsi/ (3 Agustus)

Iskandar. 2018. Pemilik Toko Hikmah mitra Kopontren, wawancara di Kopotren Al-Urwatul Wutsqaa (5 Agustus)

Mudabbir. 2018. Ketua Osis Putra, Pondok Pesantren Al-Urwatul Wutsqaa, wawancara di Kelurahan Benteng, Kecamatan Baranti, Kabupaten Sidrap (5 Agustus).

Pondok Pesantren Al-Urwatul Wutsqaa. 2018. Profil Pesantren Al-Urwatul Wutsqaa, (1 November)

Pondok Pesantren Al-Urwatul Wutsqaa. 2018. Dokumentasi peneliti di Kelurahan benteng, Kecamatan Baranti, Kabupaten Sidrap (2 Agustus)

Pondok Pesantren Al-Urwatul Wutsqaa. 2018. Ketua Koperasi, wawancara peneliti di Kelurahan benteng, Kecamatan Baranti, Kabupaten Sidrap (2 Agustus)

Rusdi, M. A. (2017). Maslahat Sebagai Metode Iitihad Dan Tujuan Utama Hukum Islam. DIKTUM: Jurnal Syariah dan Hukum, 15(2), 151-168. 
Saraswati Baharuddin, Ketua Osis Putri, Pondok Pesantren Al-Urwatul Wutsqaa, wawancara di Kelurahan Benteng, Kecamatan Baranti, Kabupaten Sidrap.

Takbir Lailatul Fitra. 2016. Struktur organisasi Koperasi Pondok Pesantren Al-Urwatul Wutsqaa,Skripsi Sarjana. UIN Alauddin Makassar; Fakultas Ekonomi dan Bisnis.

Undang-Undang Republik Indonesia Nomor 25 Tahun 1992 Tentang Perkoperasian

Wahidin. Sekertaris Pengurus Yayasan Pondok Pesantren Al-Urwatul Wutsqaa, wawancara di Kelurahan Benteng, Kecamatan Baranti, Kabupaten Sidrap (5 Agustus)

Pondok Pesantren Al-Raisiyah, https://www.researchgate.net/publication/294728312_Studi_Kasus_ Pola_Manajemen_Pondok_Pesantren_Al-Raisiyah_di_Kota_Mataram 